\title{
MICROORGANISMS IN CHRONIC OTITIS MEDIA WITH EFFUSION
}

\author{
Jha A K ${ }^{1}$, Singh J B ${ }^{1}$, Raut S $\mathbf{P}^{1}$
}

\section{ABSTRACT}

A total of 100 patient with otitis media effusion obtained from patients suffering from chronic otitis media with effusions was examined for bacterial smear and culture. In mucoid effusion $82 \%$ showed positive bacterial smear, only $35 \%$ yielded positive bacterial culture. Bacterial cultures rate was higher in serous $(50 \%)$ effusion. The isolation of common pathogens accounted for the remaining $42 \%$. The high incidence of microorganisms in the middle ear effusions in the present study indicates bacterial contribution in many cases of otitis media effusion. Concerning the sterile nature of the middle ear fluid some investigators suggested that the effusions are transudates and are created by a negative pressure in the tympanum due to a malfunctioning Eustachian tube. ${ }^{2}$ It was suggested that failure to isolate organisms may be partly due to the antimicrobial characteristics of effusions. The purpose of this study is to show possible role of bacteria in Middle Ear Effusions.

\section{Key Words: Otitis Media, Effusion, Microorganisms.}

\section{INTRODUCTION}

It is still unclear whether bacterial infection is one of the etiologic factors of chronic otitis Media with effusion. Although most investigators agree that middle ear effusions are sterile. ${ }^{1}$ Scoenturia in 1958 and other have reported that about $35 \%$ of effusion yielded bacteria in culture. Concerning the sterile nature of middle ear fluid some investigators suggested that the effusion are trunsdudate and created by negative pressure in the tympanum due to malfuncting of eustuchian tube. ${ }^{2}$ Recent studies by numerous investigators demonstrated high level of immunoglobin and lysozyme in middle ear effusion. ${ }^{3}$ Therefore it is conceivable that there may be organism in the effusion but their growth is inhibited by potent anti-microbial substances.

The purpose of this study is to show method of demonstrating bacteria in middle ear effusion and discuss the data in regard to possible role of bacteria in middle ear effusion.

1. Nepal Medical College, Kathmandu, Nepal.

Address for correspondence : Dr. Anil Kumar Jha, Assistant Professor

Nepal Medical College, Jorpati

P.O. Box: 13344, Kathmandu, Nepal.

Email: dr_akjha@hotmail.com 


\section{METHODS AND MATERIALS}

The present study was under taken in patients who attended the ENT Dept. of Om Hospital Out patients department from Oct. 1995 to Oct. 1998. A total of 100 patients were included in this study, who underwent Ventilation tube insertion for the treatment. Antibiotic therapy was stopped for at least one month prior to sample collection. The ear effusions were aspirated with Myrimgotony under general anesthesia. Samples were immediately sent to be laboratory for culture within two hours of collection. In order to investigate the possibility that effusions were contaminated with bacteria from the external ear canal during collection, ear canal cultures were made using two procedures before effusion collection, 1. Ear wax was obtained from 20 patients and placed in clinwax 2. Specimens were obtained from the external ear canal of 8 other patients using cotton swabs moistened with sterile saline. In this case, wax and debris were removed from the external ear canal before insertion of a sterile speculum and the swab was passed through to the membrane. These latter specimens were processed similarly to the effusions; in every case, corresponding effusions were collected and analyzed as done other study. ${ }^{3}$ All cultures were incubated at $37^{\circ} \mathrm{C}$ and plates were placed in $\mathrm{CO}_{2}$ candle jars. Bacterial isolates were identified by studying the Gram stain reaction as well as biochemical and nutritional characteristics. Mucoid effusions were diluted with saline and shaken with glass beads to break down the mucous strands. When the specimens were watery, they were transferred to a test tube and certifuged at $1000 \mathrm{~g}$ for 20 minutes. Studies, and two smears were made from the pellets. One smear was stained by Gram's method for observing bacteria; the other was stained by Wright's method for enumerating blood cells. Specimens were classified into serous, mucoid and leukocytic types in accordance with the physical appearance and cell content of smears.

\section{RESULTS}

Out of 100 samples, $81 \%$ effusions showed bacteria on the smear, and only $41 \%$ yielded bacteria in culture, indicating that many effusions with positive, smears contain non-viable organisms. Mucoid type effusions was most common. However, mucoid effusions had the lowest incidence (35\%) of positive cultures, while serous type had $50 \%$ and leukocytic-type had $42 \%$.

Usually only one but occasionally two types of bacteria were found on each smear. Bacteria were observed extracellularly and intracellularly. There were 7 different types of bacteria isolated from effusions of Otitis Media with Effusion (OME) patients. Besides the common human pathogens (Hemophilus influenzae, Stereptococcus pneumoniae, Group A Stereptococcus, Staphylococcus aureus), some nonpathogens such as diphtheroids, Staphylococcus epidermidis.

Branhamella catarrhalis were also isolated from a large number of specimens. H. influenzae was the most common isolate in leukocytic effucion and $\mathrm{S}$. Pneumaniae was the most common isolate in serous effusion. Diphthemid was the most common isolate in mucoid effusion.

\section{Table I}

Bacterial Isolates From Middle Ear Effusions

\begin{tabular}{|l|c|c|c|c|}
\hline \multicolumn{1}{|c|}{ Type of Effusion } & Mucoid & Serous & Leukocytic & Total \\
\hline Specimens tested & 56 & 30 & 14 & 100 \\
\hline Bacteria on smear & $46(82 \%)$ & $25(83 \%)$ & $10(71 \%)$ & $81(81 \%)$ \\
\hline Bacteria: culture positive & $20(35 \%)$ & $15(50 \%)$ & $6(42 \%)$ & $41(41 \%)$ \\
\hline
\end{tabular}




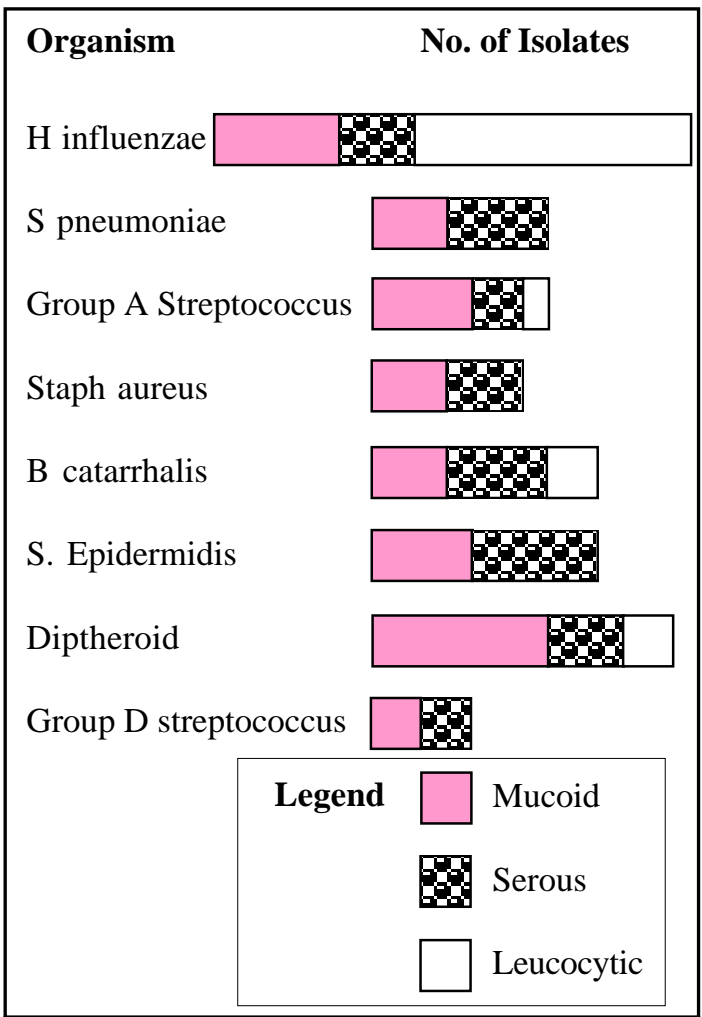

Fig 1. Bacteria isolates from culture positive cases.

\section{DISCUSSION}

This study showed approximately $41 \%$ of the effusions were bacterial culture positive, and $81 \%$ of the smears showed various organisms on gram stain. The high isolation rate in the mean but not in culture may be due to the procedure involving dilution of antimicrobial factors in effusions, which might inhibit the growth of bacteria in culture. ${ }^{4}$ The high incidence of bacteria positive smears may be due to the fact that pellets of centrifuged effusions were used for making smears. We also cannot completely rule out the possibility of contamination, which may be the reasons for the higher incidence of bacterial isolation. Since these organisms are also frequently observed in the external ear canal as normal flora, the possibility of contamination during specimen collection was carefully evaluated. The present study revealed that the organisms cultured from the effusions do not, in general, correlate well with those isolated from either the external canal or ear wax. This finding would support the notion that the nonpathogenic organisms isolated from effusions are not contaminants. However, when the isolates from the surface of the tympanic membrane are examined, there is good correlation between the organisms isolated from the effusions and those cultured from the tympanic membrane. This high positive correlation (82\%) of nonpathogens can be interpreted in several ways. 1) It could be due to contamination from the surface of the tympanic membrane. 2) The inflammatory process of the tympanic membrane influenced high nonpathogenic bacterial growth rate on its surface, but it is unrelated to the etiologies of the OME. 3) It is possible that the nonpathogens are related to OME and that the tympanic membrane in a pathologic condition is permeable to microoganisms . However, the concept that chornic middle ear effusions are sterile, accepted for decades by many clinicians, has discouraged attempts at culturing bacteria from effusions. When common human pathogens are isolated from chornic effusions, it is assumed that these are misdiagnosed cases of bacterial otitis media.

\section{CONCLUSION}

The high bacterial recovery rate in the present study may represent a high rate of treatment failure of acute otitis media as observes in other study. ${ }^{5}$ Correlating immunoglobulin levels and antibacterial enzyme (lysozyme) with the microbial isolation rate from effusions seemed to support the idea that the microbial organisms may have been involved in OME because the positive bacterial culture rate was inversely related to the levels of antimicrobial agents in the effusions, ${ }^{6}$ therefore, their presence in the effusions cannot be discounted as mere contaminants. $\mathrm{H}$. Influenzae was the most common pathogen recovered from effusions in this study, and this organisms is known to cause serous effusion in the middle ear, when infected. This 
again signifies the importance of microbiological examination of OME.

\section{REFERENCES}

1. Senturia BH, Gesssert CF, Carr CD, et al (1958): Studies concerned with tubotympanits. Ann Otol Rhinol Laryngol 67:440 - 467.

2. Silverstein $\mathrm{H}$, Miller $\mathrm{GH}$, and Lindeman RC (1966): Eustachian tube dyfunction as a cause for chronic secretory otitis in children. Laryngoscope 76: 259-273.

3. J ordan R (1969): Chronic secretory otitis media. Laryngoscope 59: 1002 - 1015.
4. Berman S. and Roark R. (1993): Factors influencing outcome in children treated with antibiotic for acute otitis Media. Paediatrics infectious disease J ournal 12: 20 - 24

5. Harsten G. Rellncer K. Hed Rup J. Kalm. O. and Korn Fact R.: (1989) treatment. Failure in acute otitis media. A clinical study of children during their first three years of life. Acta. Otol aryngologica 108: $253-258$

6. Siirala U. Vuori M (1964): Protein pattern and the bacteriostatie effect of the exudate in acute otitis media. Acta Otolaryngol 44: 197 - 204.

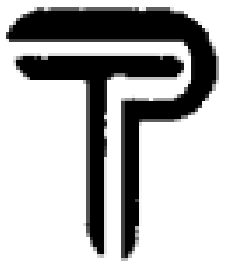

TIME Pharmaceuticals (P) Ltd.

HEAD OFFICE: Bina Road, Narayangarh, Chitwan, Nepal.

Tel. \# 056-23804, Fax \# 977-56-20759

Email: cifrox@wlink.com.np

FACTORY: Mukundapur, Ward \# 5, Nawalparasi, Nepal Tel. \# 26391

MARKETING AND LIASION OFFICE : GPO Box \# 5591, Anam Nagar, Kathmandu, Nepal. Tel. \# 01-249944

Let's be committed and work together towards self-reliance. Let's build the Pharmaceuticals Industry image.

Our Range of Products

Uncoated Tablets: Folvin, Nausinorm, Paraflam, Sinex, Terfin 60, Timol, Wormstat (Chewable)

Film-Coated Tablets: Cifrox 500, Flam 400, Met 400, Metdil

Capsules: Himox 250/500, Broclox, Femax and Becomin

Dry Syrups: Himox, Broclox

Ointments and creams: Betatime, Gentime, Clotime, Salif, Beclotime

Our endeavor is to provide quality products to all, always at an affordable price.

\section{Our Concern Human Concern.}

